\title{
Soil concrete based on waste of heat power engineering and siftings of rock grinding
}

\author{
Natalia Konovalova, Elena Rush, Dmitry Bespolitov and Pavel Pankov \\ Irkutsk State Transport University, Irkutsk, Russian Federation
}

\begin{abstract}
The possibility of recycling large-tonnage waste of heat power engineer-ing and mining industry in road construction is shown. Compositions of road-building materials were researched, containing siftings of rock grinding, fly ash, Portland cement, modified with a stabilizing additive of polymeric nature. X-ray phase analysis showed availability of quartz in fly ash, calcite, feldspars, goethite and X-ray amorphous phase, what is consistent with the data of infrared spectroscopy. By atomic emission spectrometry with inductively coupled plasma it was revealed that fly ash is latent-active and can be disposed in compositions in the presence of a stabilizing additive. The X-ray phase analysis of grinding siftings showed that it contains quartz, feldspars, chlorite, calcite and dolomite. The specific activity of natural radionuclides (226Ra, 232Th, 40K) of fly ash and grinding siftings was 248 and $110 \mathrm{~Bq} / \mathrm{kg}$, which allows using such waste in construction without restrictions. It was revealed that the initial mineral raw materials belong to multiphase polymineral systems; therefore, when modifying them with stabilizing additives, binding of finely divided particles should be taken into account. It was revealed that the optimal content of Portland cement and fly ash in samples is 8 and $10 \mathrm{wt} . \%$. It was found that an increase in the mass fraction of fly ash in the composition of soil-concrete up to $30 \mathrm{wt} . \%$ leads to softening of the samples and a decrease in their strength characteristics.
\end{abstract}

\section{Introduction}

The most important environmental problem nowadays is the safe handling of industrial waste, which is the main source of environmental pol-lution [1, 2]. In this regard, there is a tendency towards decreasing the num-ber of waste and introduction of technologies for their safe disposal throughout the world [3-5].

The mining industries account for the largest amount of large-tonnage waste $[1,6]$. The extraction of mineral raw materials is accompanied by extraction of a sufficiently large number of overburden and containing rocks, which are stored in dumps, causing irreparable damage to the en-vironment. These rocks are not suitable for agricultural purposes, occupy significant areas, lead to environmental degradation in the adjacent territo-ries [7]. Extraction, transportation, as well as primary processing of mineral raw materials leads to violation of the structure and integrity of ecosystems, change in topography, formation of dips and subsidence of the earth's sur-face, dust formation, pollution of surface and soilwaters, and erosion of soil [8-11]. Therefore, the issues on introduction of large-tonnage waste into technological chains as non-traditional raw material in order to obtain new types of various products [12] are of highpriority. Drawing of production waste into economic circulation will contribute to the rational and costeffective use of natural mineral raw materials, since this process will not entail an increase in the costs of its extraction and processing.

Accumulated waste from mining industry and fuel and energy com-plex can be used in large quantities in the construction industry, which is the main materialintensive sector of the national economy [13, 14]. However, manufacturers of building materials prefer primary natural materials, there-fore, the resource potential of waste is not fully utilized due to a number of technological, economic, and social reasons. At the same time, large-tonnage waste has a resource potential, the involvement of which in the production of road-building materials can significantly reduce the use of primary mineral raw materials, solve the problems of rational nature management, and reduce the cost of production $[1,15]$.

The deficit of standard road-building materials is the main reason for the rise in the cost of road construction. The use of local mineral raw mate-rials, improved by stabilizing additives of various nature, can be an effective way to reduce material and technical costs. Quick utilization of waste from the mining industry and the fuel and energy complex is promising when they are introduced into the soil concrete used when forming structural layers of road pavement, basements, foundations of buildings and structures, sites of various purposes [16-20].

The use of soil concrete in the construction of road pavements has been mastered for over 50 years and has 
scientific, methodological and regulatory support. However, structural layers of mineral raw materials reinforced only with cement are characterized by low crack resistance, due to the peculiarities of the material structure, as well as the applied dynamic and climatic loads. To ensure the durability of soil concrete, it is advisable to use various stabilizing additives. Utilization of mining waste is constrained by the heterogeneity of their properties and composition. There is no sufficient research data on this theme in scientific and technical literature.

The purpose of this work was to study the characteristics, composi-tion, and structural features of mining waste (siftings of rock) and ash and slag waste for their disposal in road construction.

\section{Methods}

X-ray phase analysis of siftings of rock grinding was performed by powder diffraction using the D8 Advance X-ray diffractometer (Bruker AXS, Germany) with the following characteristics: $\mathrm{CuK}_{\alpha}$ radiation, $\mathrm{U}=40 \mathrm{kV}$, $\mathrm{I}=40 \mathrm{~mA}$, Goebel mirror, Soller slots of $2.5 \mathrm{~mm}$, scintillation counter, $2 \theta=3-60^{\circ}$, scan step of $0.02^{\circ}$, exposure was $1 \mathrm{~s} /$ step. The fly ash, grinded in an agate mortar with alcohol, was examined using the DRON 3.0 X-ray diffractometer with the following characteristics: $\mathrm{CuK}_{\alpha}$ radiation, Ni filter, $\mathrm{V}=25 \mathrm{kV}, \mathrm{I}=20$ $\mathrm{mA}, 2 \theta$ in the range of $3-65^{\circ}$, scanning step of $0.05^{\circ}$. The phase composition of samples was identified using the EVA phase search program (Diffrac ${ }^{\text {plus }}$ PDF-2, 2007). The RIR method [21] was used to carry out a semiquantitative analysis of certain phases in samples using corundum numbers of mineral phases from the PDF-2 crystallographic database (2007). The samples' microstructure was studied using the JSM-6510LV JEOL scanning electron microscope (Japan) with a microanalysis system, namely the INCA Energy 350 energy dispersive X-ray spectrometer (Oxford Instruments, Great Britain). A thin layer of platinum was deposited onto a non-conducting sample using the JFC1600 setup (United Kingdom). IR spectra were recorded using the SHIMADZU FTIR-8400S infrared Fourier spectrometer on tablets prepared according to standard procedures from well-calcined $\mathrm{KBr}$ powder containing 0.1-5.0 wt. \% of the test sample with thorough grinding in an agate mortar. The chemical composition of fly ash and Portland cement was determined by inductively coupled plasma atomic emission spectrometry using the Optima 5300DV emission spectrometer for 167-403 nm (PerkinElmer, USA). Samples were pre-dissolved in a mixture of $\mathrm{HCl}, \mathrm{HNO}_{3}, \mathrm{HClO}_{4}$ and $\mathrm{HF}$ acids.

\section{Results and Discussion}

The fly ash under investigation is a light gray powder and has the following aluminosilicate composition $(\omega$, wt.\%): 36.1 of $\mathrm{SiO}_{2} ; 10.2$ of $\mathrm{Al}_{2} \mathrm{O}_{3} ; 7.80$ of $\mathrm{Fe}_{2} \mathrm{O}_{3}$; 1.42 of $\mathrm{MgO} ; 0.56$ of $\mathrm{Na}_{2} \mathrm{O} ; 1.21$ of $\mathrm{K}_{2} \mathrm{O} ; 0.41$ of $\mathrm{TiO}_{2}$; 0.61 of $\mathrm{SO}_{3} ; 9.37$ of $\mathrm{CaO} ; 0.4$ of $\mathrm{CaO}_{\text {free. }}$. Wastes from the heat power industry in terms of $\mathrm{CaO}$ content are classified as hidden-active. The specific surface area of the particles was $276 \mathrm{~m}^{2} / \mathrm{kg}$. The specific activity of natural radionuclides $\left({ }^{226} \mathrm{Ra},{ }^{232} \mathrm{Th},{ }^{40} \mathrm{~K}\right)$ was $248 \mathrm{~Bq} / \mathrm{kg}$, which enables this waste usage in construction without restrictions.

According to infrared spectroscopy, the ash contains calcite, as evidenced by absorption bands with maxima at $1454 ; 1435$ and $876 \mathrm{~cm}^{-1}$, associated with valence and deformation vibrations of the $\mathrm{CO}_{3}{ }^{2-}$ group (Fig. 1a). The presence of quartz and cristobalite in ash is evidenced by characteristic bands with maxima at 797; $779 \mathrm{~cm}^{-1}$ and 692; $671 \mathrm{~cm}^{-1}$, respectively. Hematite has absorption bands with maxima at 563 and $461 \mathrm{~cm}^{-1}$ (Fe-O), and bands at 3458 and $1092 \mathrm{~cm}^{-1}$ correspond to valence vibrations of $\mathrm{OH}-$ and $\mathrm{Si}-\mathrm{O}-\mathrm{Si}(\mathrm{Al})$ groups.

The ash investigation by differential scanning calorimetry (DSC) and thermogravimetry (TG) revealed thermal activity of the sample (Fig. 1b). The mass loss accompanying the exoeffect with a maximum at 493.5 ${ }^{\circ} \mathrm{C}$ was $1.89 \%$. No steps associated with decomposition of carbonates are observed; small jumps in the mass loss rate increase at 680 and $715{ }^{\circ} \mathrm{C}$ are observed. When heated from 25 to $400{ }^{\circ} \mathrm{C}$, the sample loses $0.3 \%$ of adsorbed moisture.

$\mathrm{X}$-ray phase analysis showed that the ash has the following phase composition: quartz, calcite, feldspar, goethite and X-ray amorphous phase.
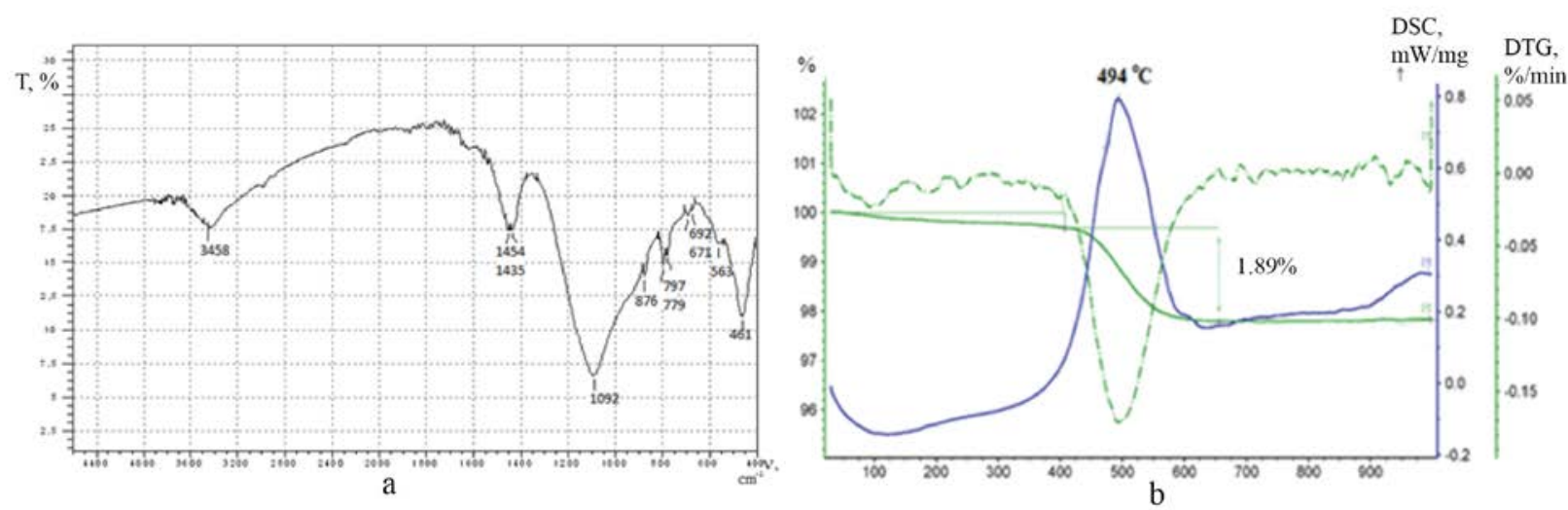

Fig. 1. Infrared spectrum (a) and thermogram (b) of fly ash. 

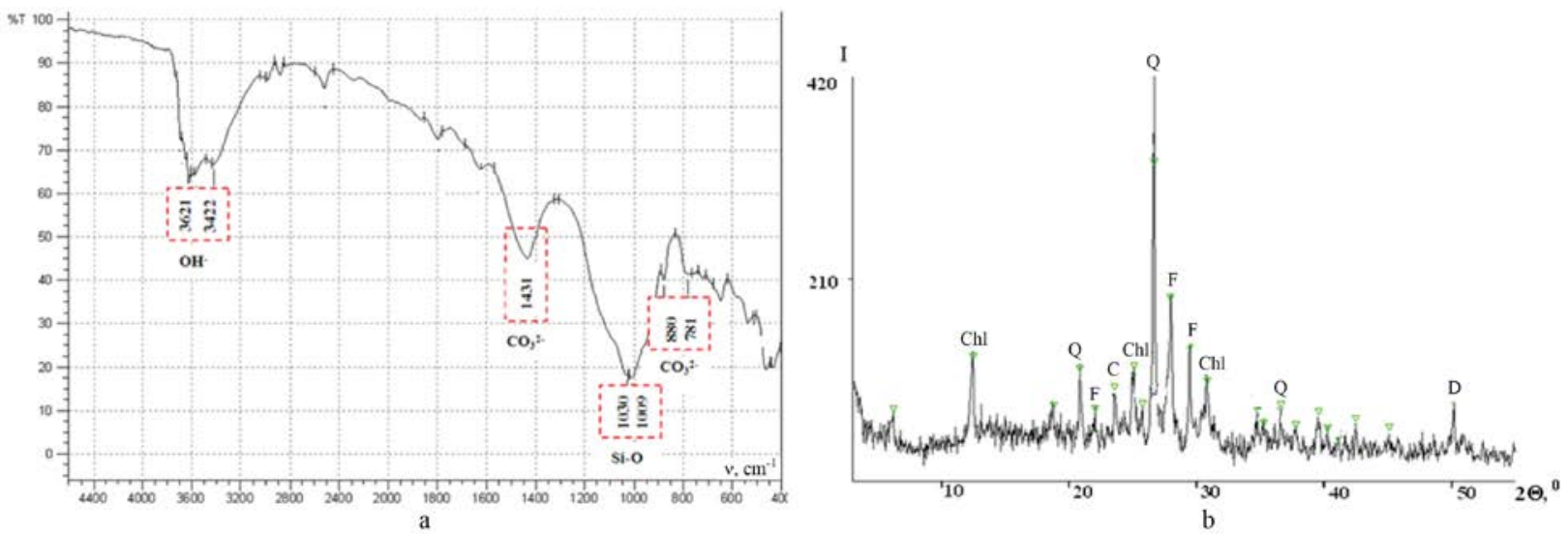

Fig. 2. Infrared spectrum (a) and diffraction pattern (b) of grinding siftings: Q - quartz; C - calcite; F- feldspars; Chl- chlorite; D - dolomite.

The siftings of rock grinding of 0-5 $\mathrm{mm}$ fraction has a bulk density of $1397 \mathrm{~kg} / \mathrm{m}^{3}$, the content of dust and clay particles is $7.3 \%$. The specific effective activity of natural radio nuclides $\left({ }^{226} \mathrm{Ra},{ }^{232} \mathrm{Th},{ }^{40} \mathrm{~K}\right)$ was $110 \mathrm{~Bq} / \mathrm{kg}$; therefore, grinding siftings can be used in the construction industry without restrictions. The data obtained by scanning electron microscopy show that the considered siftings are heterogeneous in its dispersed composition and contains irregular granular particles less than $1 \mathrm{~mm}$ in size.

Infrared spectroscopy (Fig. 2 a) showed that the siftings contain calcite, as evidenced by absorption bands with maxima at 1431; 880 and $721 \mathrm{~cm}^{-1}$, associated with valence and deformation vibrations of the $\mathrm{CO}_{3}{ }^{2-}$ group. Absorption bands with maxima at 3621 and $3422 \mathrm{~cm}^{-1}$ correspond to valence vibrations of hydroxyl groups bound by hydrogen bonds, and with maxima at $1628 \mathrm{~cm}^{-}$ 1 correspond to deformation vibrations of $\mathrm{H}-\mathrm{O}-\mathrm{H}$ crystallization water. Absorption bands are observed at 1030 and 1009, as well as at 463 and $436 \mathrm{~cm}^{-1}$, which belong to valence and deformation vibrations of Si-O bonds of silicates.

The X-ray phase analysis of grinding siftings (Fig. 2 b) showed that it contains quartz $\mathrm{SiO}_{2}(4.26 ; 3.35 ; 2.45$ $\AA$ ), feldspars $\mathrm{NaAlSi}_{3} \mathrm{O}_{8}(4.04 ; 3.19 ; 2.99 \AA)$, chlorite $(\mathrm{Mg}, \mathrm{Al})_{6}(\mathrm{Si}, \mathrm{Al})_{4} \mathrm{O}_{10}(\mathrm{OH})_{8}(7.14 ; 3.56 ; 2.85 \AA$ ) $)$ calcite
$\mathrm{CaCO}_{3}$ (3.77; 3.03; $2.45 \AA$ ), dolomite $\mathrm{CaMg}\left(\mathrm{CO}_{3}\right)_{2}$ (2.90; $1.79 \AA)$.

To ensure optimal strength characteristics of soil concrete, the content of the main structure-forming minerals of Portland cement is important, as well as its chemical composition. Figure 3 shows diffractogram and thermogram of the binder.

X-ray phase analysis of Portland cement (Fig. 3a) showed that it includes alite $\mathrm{Ca}_{3} \mathrm{SiO}_{5}(5.95 ; 3.03 ; 2.97$; 2.74; $2.18 \AA$ ), beliteCa $\mathrm{SiO}_{4}$ (3.43; 2.88; 2.81; 2.28; $1.76 \AA)$, portlandite $\mathrm{Ca}(\mathrm{OH})_{2}(3.19 ; 2.65 \AA)$ and silica $\mathrm{SiO}_{2}$ (3.35; 2.44; $2.32 ; 2.21 ; 2.11 ; 1.82 \AA$ ). The phase composition of Portland cement is confirmed by the data obtained by differential scanning calorimetry and thermogravimetry (Fig. 3 b). The basic chemical composition of Portland cement ( $\omega$, wt.\%) is the following: 6.75 of $\mathrm{Al}_{2} \mathrm{O}_{3} ; 36.55$ of $\mathrm{CaO} ; 4.41$ of $\mathrm{Fe}_{2} \mathrm{O}_{3}$; 4.04 of $\mathrm{MgO} ; 27.90$ of $\mathrm{SiO}_{2} ; 2.80$ of $\mathrm{SO}_{3}$.

Thus, the initial mineral raw material is a multi-phase polymineral system, therefore, when modifying them with stabilizing additives, attention should be paid to the binding of finely divided particles. Establishing the relationship between physic-mechanical characteristics of samples and the content of Portland cement and ash will make it possible to control the strength of soil
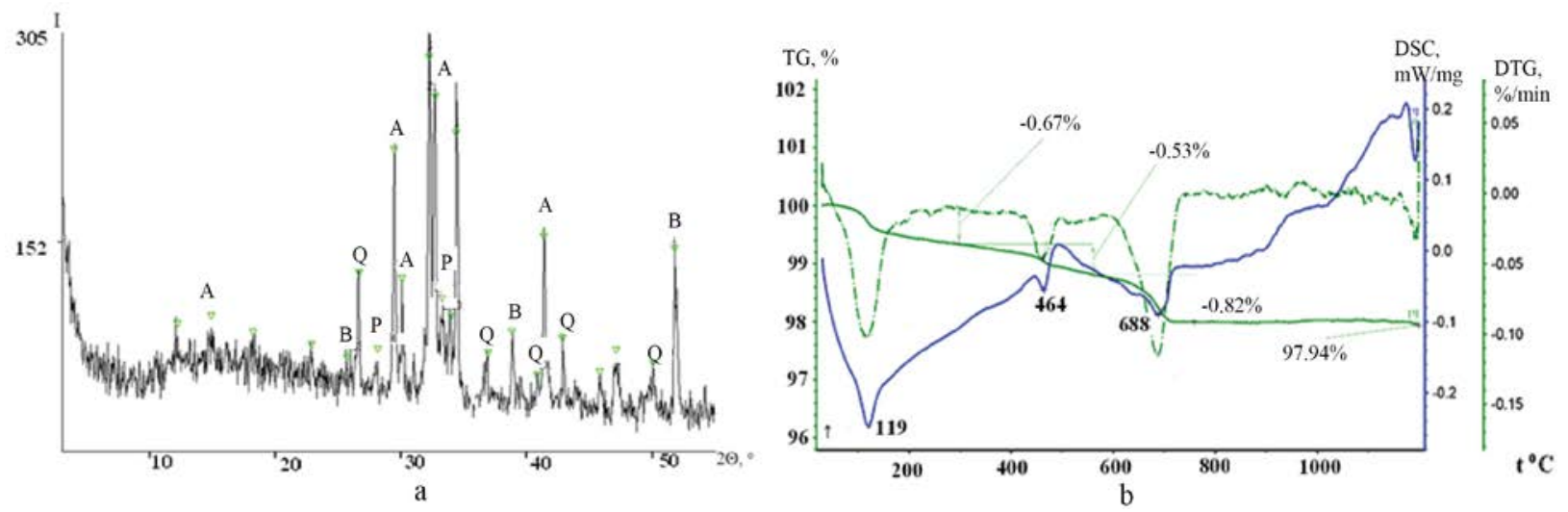

Fig. 3. The diffractogram (a) and thermogram (b) of Portland cement (A - alite; B - belite; P - portlandite; Q - quartz). 
Table 1. Physico-mechanical characteristics of samples.

\begin{tabular}{|c|c|c|c|c|}
\hline \multirow{2}{*}{ Samples } & \multicolumn{2}{|r|}{$\omega$, wt. $\%$} & \multirow{2}{*}{$\begin{array}{l}\text { Compression } \\
\text { strength, MPa }\end{array}$} & \multirow{2}{*}{$\begin{array}{c}\text { Bending } \\
\text { strength, MPa }\end{array}$} \\
\hline & Ash & Portland cement & & \\
\hline $\mathrm{I}_{\mathrm{a}}$ & 10 & \multirow[t]{3}{*}{ 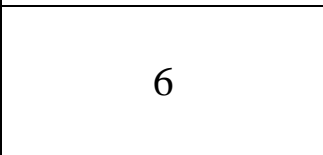 } & 4.2 & 0.8 \\
\hline $\mathrm{I}_{\mathrm{b}}$ & 20 & & 3.1 & 0.5 \\
\hline $\mathrm{I}_{\mathrm{C}}$ & 30 & & 2.9 & 0.4 \\
\hline $\mathbf{I I}_{\mathbf{a}}$ & 10 & \multirow{3}{*}{8} & 6.3 & 1.2 \\
\hline $\mathrm{II}_{\mathrm{b}}$ & 20 & & 4.1 & 0.8 \\
\hline $\mathrm{II}_{\mathrm{C}}$ & 30 & & 3.5 & 0.5 \\
\hline $\mathrm{III}_{\mathrm{a}}$ & 10 & \multirow{3}{*}{10} & 7.3 & 1.2 \\
\hline $\mathrm{III}_{\mathrm{b}}$ & 20 & & 4.3 & 0.8 \\
\hline $\mathrm{III}_{\mathrm{C}}$ & 30 & & 3.3 & 0.5 \\
\hline
\end{tabular}

concrete.

The optimal dosages of raw materials are determined based on experience. The mass fractions of Portland cement (6, 8, 10 wt.\%) and fly ash (10, 20, 30 wt.\%) were varied in the composition of soil concrete. It was experimentally established that the optimal content of the stabilizing additive was 1 wt.\%. The relationship between physico-mechanical characteristics of samples and the mass fraction of raw materials is given in table 1.

Analysis of data (Table 1) showed that the optimal content of Portland cement and ash is 8 and $10 \mathrm{wt} \%$ $\left(\mathrm{II}_{\mathrm{a}}\right)$. It has been established that the physico-mechanical characteristics of samples containing 8 and $10 \mathrm{wt} \%$ of binder $\left(\mathrm{II}_{\mathrm{a}-\mathrm{c}}, \mathrm{III}_{\mathrm{a}-\mathrm{c}}\right)$ differ slightly from each other, so the introduction of 10 wt.\% of Portland cement is economically inefficient. It was found that an increase in ash content up to 30 wt.\% contributes to the process of gradual decompression of samples and, consequently, a decrease in their strength characteristics, including frost resistance.

\section{Conclusions}

1. The conducted studies have shown the fundamental possibility of using mining waste and ash and slag waste as components of road soil-concrete.

2.A set of modern methods (atomic-emission spectrometry with inductively coupled plasma, differential scanning calorimetry and thermogravimetry, scanning electron microscopy, X-ray phase analysis, infrared spectroscopy) were used to study the chemical and phase composition, physico-chemical, physical properties of rock grinding siftings and fly ash. The studied wastes are multiphase polymineral systems and their important component is grouting of finely divided particles. It was revealed that the specific effective activity index of natural radionuclides $\left({ }^{226} \mathrm{Ra},{ }^{232} \mathrm{Th},{ }^{40} \mathrm{~K}\right)$ of the studied wastes is less than $370 \mathrm{~Bq} / \mathrm{kg}$, which allows them to be used in the construction industry without restrictions. The hydraulic properties of ash are classified as hidden-active and can be disposed in soil concrete compositions modified by stabilizing additives.
The relationship between strength characteristics of the soil-concrete modified with a stabilizing additive and the mass fraction of binder and ash is shown. It was found that to obtain road soil concrete with maximum strength, the optimal ash and Portland cement content was 10 and 8 wt.\%.

\section{References}

1.E. Matinde, G. S. Simate, and S. Ndlovu, Journal of the Southern African Institute of Mining and Metallurgy, 118, 825-844 (2018)

2.Z. Bian, X. Miao, S. Lei, S.-E. Chen, W. Wang, and S. Struthers, Science, 337, 702-703 (2012)

3.B. K. Sarkar, M. G. Dastidar, R. Dey, and G. C. Das, Canadian Metallurgical Quarterly, 58, 299-307 (2019)

4.G. Yang, W. Zhang, and D. Zha, Journal of Cleaner Production, 216, 14-24 (2019)

5.Z. Sas, N. Vandevenne, R. Doherty, R. Vinai, J. Kwasny, M. Russell, W. Sha, M. Soutsos, and W. Schroeyers, Science of the Total Environment, 658, 141151 (2019)

6. M. C. Kasemodel, I. K. Sakamoto, M. B. A. Varesche, and V. G. S. Rodrigues, Science of the Total Environment, 675, 367-379 (2019)

7.S. J. Brooks, C. Escudero-Onate, and A. D. Lillicrap, Chemosphere, 233, 818-827 (2019)

8.P. Krechetov, O. Chernitsova, A. Sharapova, and E. Terskaya, Journal of Soils and Sediments, 19, 31393154 (2019)

9. T. Ma, Y. Sheng, Y. Meng, and J. Sun, Chemosphere, 225, 83-92 (2019)

10. P. Shi, Y. Zhang, Z. Hu, K. Ma, H. Wang, and T. Chai, Applied Soil Ecology, 121, 1-10 (2017)

11. M. L. García-Lorenzo, J. Marimón, M. C. Navarro-Hervás, C. Pérez-Sirvent, M. J. MartínezSánchez, and J. Molina-Ruiz, Environmental Science and Pollution Research, 23, 6014-6023 (2016)

12. A. J. Calderón Márguez, P. C. Cassettari Filho, E. W. Rutkowski, and R. de Lima Isaac, Journal of Cleaner Production, 226, 1102-1115 (2019) 
13. S. Murtazaev, M. Salamanova, M. Saidumov, and A. Alaskhanov, Ecology and Industry of Russia, 22(6), 49-53 (2018)

14. Y. Barabanshchikov, I. Fedorenko, S. Kostyrya and K. Usanova, Advances in Intelligent Systems and Computing, 983, 858-866 (2019)

15. L. Zengxiang, and C. Meifeng, Procedia Environmental Sciences, 16, 715-721 (2012)

16. B. Cetin, A.H. Aydilek, and Y. Guney, Resources, Conservation and Recycling, 54, 878-892 (2010)

17. J. Fan, D. Wang, and D. Qian, Journal of Rock Mechanics and Geotechnical Engineering, 10, 791797 (2018)

18. T. B. Edil, H. A. Acosta, and C. H. Benson, Journal of Materials in Civil Engineering, 18, 283-294 (2006)

19. S. Bin-Shafique, K. Rahman, M. Yaykiran, and I. Azfar, Resources, Conservation and Recycling, 54, 666-672 (2010)

20. S. R. Kaniraj, and V. G. Havanagi, Cement and Concrete Research, 29, 673-677 (1999)

21. C. R. Hubbard, E. H. Evans, and D. K. Smith, Journal of Applied Crystallography, 9, 169-174 (1976) 